\title{
ANTI-ULCER ACTIVITY OF HYDROALCOHOLIC EXTRACT OF PIPER BETLE LEAF ON EXPERIMENTAL ANIMALS
}

\author{
URMISTHA SARKAR*, ANKIT SAHA, MRITYUNJOY MAJUMDAR \\ Department of Pharmacology, Netaji Subhas Chandra Bose Institute of Pharmacy, Chakdaha, Nadia, India. \\ E-mail: urmisthasarkar@gmail.com
}

Received: 8 April 2017, Revised and Accepted: 28 May 2017

\section{ABSTRACT}

Objective: The main objective of this study is to establish the anti-ulcer activity of hydroalcoholic extract of Piper betle leaf on experimental animals based on previously existing aspects such as antioxidant, antihistaminic, and antimicrobial properties of $P$. betle leaf

Methods: The leaves were collected, shed dried, and extracted by the Soxhlet apparatus using $70 \%$ ethanol. The anti-ulcer activity of the extract was evaluated in albino Wistar rats employing pyloric ligation and stress-induced antiulcer models. Ranitidine was served as a standard drug in both the models. The significance of activity was assessed using a one-way analysis of variance followed by Dunnett's post-parametric test.

Results: In the pyloric ligation model, the untreated control has shown $4.3 \mathrm{mEq} / \mathrm{l}$ of acidity, whereas the ranitidine-treated standard group shown $2 \mathrm{mEq} / \mathrm{l}$ and $P$. betle has shown $2.5 \mathrm{mEq} / \mathrm{l}$ acidity, respectively. In the stress-induced antiulcer model, the activity was more prominent, in the untreated control, there was 26 number of sores present, whereas the standard group showed only one number of ulcer sore, and in the $P$. betle treated group, there was four number of ulcer sores present.

Conclusion: In the present study, P. betle exhibited potent antiulcer potential while compared with the untreated control and the activity is comparable with standard ranitidine. From the above findings, it can correlate the use of betel leaf as a digesting or gastroprotective agent.

Keywords: Antiulcer, Piper betle, Pyloric ligation, Stress-induced model.

(C) 2019 The Authors. Published by Innovare Academic Sciences Pvt Ltd. This is an open access article under the CC BY license (http://creativecommons. org/licenses/by/4. 0/) DOI: http://dx.doi.org/10.22159/ajpcr.2019.v12i7.33232

\section{INTRODUCTION}

An ulcer is one of the major gastrointestinal disorders, which occurs due to an imbalance between offensive (gastric acid, pepsin, bile, and oxidative stress) and defensive (mucus, prostaglandin, and blood flow) factors [1]. An ulcer in the stomach is known as gastric ulcer and when it appears in the first part of the intestine is called duodenal ulcer [2]. Common causes which are responsible for peptic ulcer are Helicobacter pylori [3], NSAIDs [4], tobacco smoking [5], Crohn's disease [6], etc. It shows various symptoms such as upper abdominal pain, belching, and vomiting with some complications such as bleeding, perforation, and blockage of stomach. The medication used to either decrease acid secretion (proton-pump inhibitor, $\mathrm{H}_{2}$ blocker, and prostaglandin analog) or neutralize the acid secreted in the stomach (antacids). Stop smoking, alcohol, and NSAID consumption help to heal the ulcer rapidly [7,8].

Nowadays, ulceration constitutes a major problem in a vast developing country like India. According to the latest WHO data published in May $2014,0.96 \%$ or 85,487 deaths are occurring by peptic ulcer disease. In the case of ulceration, India gets the $26^{\text {th }}$ rank in the world for the death rate [9].

In recent years, people show interest in using natural products other than conventional drugs, which exert more adverse effects side by its desired effect. Piper betle is a heart-shaped leaf belonging to the family Piperaceae. Betel leaf is frequently consumed in Asia with areca nut and/or tobacco [10]. P. betle exhibits lots of medicinal activities such as antioxidants [11], antihistaminic [12], and antimicrobial [13] which are scientifically proven. Conventionally, betel leaf also used to treat stomach problems including gastric ulcer, but relevant scientific data are not available. A drug possesses three important activities such as antioxidant, antihistaminic, and the antimicrobial is obvious to have antiulcer activity because oxidative stress is initiate and aggravates the peptic ulcer [14], and antihistaminic blocks histamine release and prevents ulcer production. In this study, there is an attempt to investigate the reason behind the traditional uses of $P$. betle leaves as gastroprotective agents.

\section{MATERIALS AND METHODS}

\section{Animal}

Albino Wistar rat weighing 150-200 g either sex is used for the study in different models and placed in polypropylene cages $(32 \mathrm{~cm} \times 24 \mathrm{~cm} \times 16 \mathrm{~cm})$. The animals were purchased from an authorized animal breeder. The animals were kept in CPCSE approved NSCBIP animal house (approval no: 1502/P0/a/11/CPCSEA), well maintained under standard hygienic conditions, at a temperature $\left(22 \pm 2^{\circ} \mathrm{C}\right), 65 \%$ relative humidity, and 12-h light and dark cycle. Commercial food pellets and tap water ad libitum were provided. All experiments were conducted between 10 am and $6 \mathrm{pm}$.

\section{Plant extract}

Leaves of $P$. betle were collected and the specimen was authenticated by the botanist. The leaves were washed gently with fresh water and shed dried. Leaves were made coarse by hand crush and subjected to Soxhlet extraction using $70 \%$ ethanol for consecutive $48 \mathrm{~h}$. The extract was dried using desiccators.

\section{Preparation of drug solution}

The extract was dissolved in distilled water to prepare a stock solution of $150 \mathrm{mg} / \mathrm{kg}$. Ranitidine was dissolved in distilled water to prepare the solution $20 \mathrm{mg} / \mathrm{kg}$.

\section{Chemicals and drugs}

Formalin, ethanol, sodium hydroxide $(\mathrm{NaOH})$, and hydrochloric acid were obtained from Loba Chemie Pvt., Ltd., while ranitidine (Rantac (R) 
$150 \mathrm{mg}$ by JB Chemicals and Pharmaceutical Ltd.), diethyl ether was purchased from Merck Specialities Pvt. Ltd., Mumbai.

\section{Acute oral toxicity studies}

The acute toxicity study was performed as per the OPPTS guideline applying up and downhill methods [15].

\section{Preliminary phytochemical investigations of the extracts}

Hydroalcoholic extracts of $P$. betle leaf were evaluated for the phytochemical investigation to check the presence of various phytoconstituents such as alkaloid, carbohydrates, saponin, flavonoids, glycosides, tannins, and proteins [16]

\section{Experimental procedures}

\section{Antiulcer activity by pyloric ligation}

Albino Wistar rats were divided into three groups, each group contains six animals. Animals fasted for $24 \mathrm{~h}$. The $1^{\text {st }}$ group received normal saline $2 \mathrm{ml} / \mathrm{kg}$ (control), the $2^{\text {nd }}$ group received ranitidine $20 \mathrm{mg} / \mathrm{kg}$ by oral route (standard), and the third group received a hydroalcoholic extract of $P$. betle $(150 \mathrm{mg} / \mathrm{kg}$ ) by the oral route, $30 \mathrm{~min}$ before to pyloric ligation. Animals were sacrificed $4 \mathrm{~h}$ later and the stomach was opened to collect the gastric content. The total volume of gastric content was measured [17]. Centrifugation of gastric content was done at $1000 \mathrm{rpm}$ for $10 \mathrm{~min}$. About $1 \mathrm{ml}$ of the supernatant liquid was pipette out and diluted to $10 \mathrm{ml}$ with distilled water. The solution was titrated against $0.01 \mathrm{~N} \mathrm{NaOH}$ using phenolphthalein as an indicator, to the endpoint when the solution turned an orange color. The volume of $\mathrm{NaOH}$ needed was taken according to the free acidity $[18,19]$. Titration was further continued until the solution regained a pink color. The volume of $\mathrm{NaOH}$ required was noted and was taken as corresponding to the total acidity. Acidity was expressed as follows [20]:

$$
\text { Acidity }=\frac{\text { Volume of } \mathrm{NaOH} \text { normality } 100 \mathrm{mEq} / \mathrm{L}}{0.1}
$$

Stress - induces antiulcer activity by water immersion model

The procedure for inducing ulcers with the water immersion stressinduced ulcer model includes animals being fasted for a period of $24 \mathrm{~h}$ before the experiment. The animals were divided into three groups each containing six number of animals. The $1^{\text {st }}$ group received normal saline $2 \mathrm{ml} / \mathrm{kg}$ (control), the $2^{\text {nd }}$ group received ranitidine $20 \mathrm{mg} / \mathrm{kg}$, and the $3^{\text {rd }}$ group received hydroalcoholic extract of $P$. betle $(150 \mathrm{mg} / \mathrm{kg})$ by oral route, after $30 \mathrm{~min}$ of the treatment, the animals were placed individually in a restricted cage and immured them in water tank $\left(20^{\circ} \mathrm{C}-23^{\circ} \mathrm{C}\right)$ for $4 \mathrm{~h}$. After $4 \mathrm{~h}$, the animals were taken out from the water immersion cage and sacrificed. The stomach of each animal was isolated, mounted and the number of ulcer formation was counted for evaluation [21-23]

\section{Statistical analysis}

The experimental data were expressed as mean \pm SEM for each treatment group. The significance of activity was assessed using a one-way analysis of variance followed by Dunnett's post-parametric test between the data of control and treated groups. ${ }^{*} \mathrm{p}<0.05$ was considered statistically significant.

\section{RESULTS AND DISCUSSION}

\section{Extract preparation}

The leaves of $P$. betle were subjected to Soxhlet extraction using $70 \%$ ethanol for consecutive $48 \mathrm{~h}$ and $12 \%$ yield was obtained.

\section{Acute oral toxicity studies}

The acute toxicity study of the extracts obtained from the leaves of $P$. betle was performed as per the OPPTS guideline and found that $2000 \mathrm{mg} / \mathrm{kg}$ dose was safe.

\section{Preliminary phytochemical investigation}

The extracts obtained from the leaves of $P$. betle were subjected for preliminary investigation and followed that observations were found Table 1.

\section{Antiulcer activity by pyloric ligation}

The anti-ulcer activity of hydroalcoholic extract of P. betle was evaluated in albino Wistar rats employing pyloric ligation [Table 2]. In the pyloric ligation model, the untreated control has shown $4.3 \mathrm{mEq} / \mathrm{l}$ of acidity, whereas the ranitidine-treated standard group shown $2 \mathrm{mEq} / \mathrm{l}$ and P.betle has shown $2.5 \mathrm{mEq} / \mathrm{l}$ acidity, respectively [Fig. 1].

\section{Stress-induced antiulcer activity by water immersion mode}

In the stress-induced antiulcer model, the activity was more prominent; in the untreated control, there was 26 number of pores present, whereas the standard group showed only one number of ulcer pore, and in the $P$. betle treated group, there was four number of ulcer pores present [Table 3 and Figs. 2 and 3].

Oxidation is a chemical reaction by which free radicals produces; these free radicals are dangerous for the living cells and tissues in our body.

Table 1: A preliminary phytochemical investigation of Piper betle leaves extract

\begin{tabular}{lll}
\hline S. No. & Test names & Results \\
\hline 1 & Test for alkaloid & Positive \\
2 & Test for carbohydrates & Positive \\
3 & Test for steroids & Positive \\
4 & Test for saponins & Positive \\
5 & Test for tannins & Positive \\
6 & Cardiac glycoside & Positive \\
7 & Flavonoids & Positive \\
\hline
\end{tabular}

Table 2: Acidity index (mEq/l) in the pyloric ligation model

\begin{tabular}{ll}
\hline Groups & Acidity index (mEq/l) \\
\hline Control & $4.3 \pm 0.33$ \\
Standard & $2 \pm 0.16^{* *}$ \\
Piper betle & $2.5 \pm 0.31^{* *}$ \\
\hline
\end{tabular}

All values are mean \pm SEM, $\mathrm{n}=6,{ }^{*} \mathrm{p}<0.05,{ }^{* *} \mathrm{p}<0.01,{ }^{* * *} \mathrm{p}<0.001$, versus vehicle control

Table 3: Ulcer index (number of pores in the stomach) in water immersion model

\begin{tabular}{ll}
\hline Groups & Number of pores in stomach \\
\hline Control & $26 \pm 1.26$ \\
Standard & $1 \pm 0.21^{* * *}$ \\
Piper betle & $4 \pm 0.36^{* * *}$ \\
\hline
\end{tabular}

All values are mean \pm SEM, $n=6,{ }^{*} \mathrm{p}<0.05,{ }^{* *} \mathrm{p}<0.01,{ }^{* * *} \mathrm{p}<0.001$, versus vehicle control

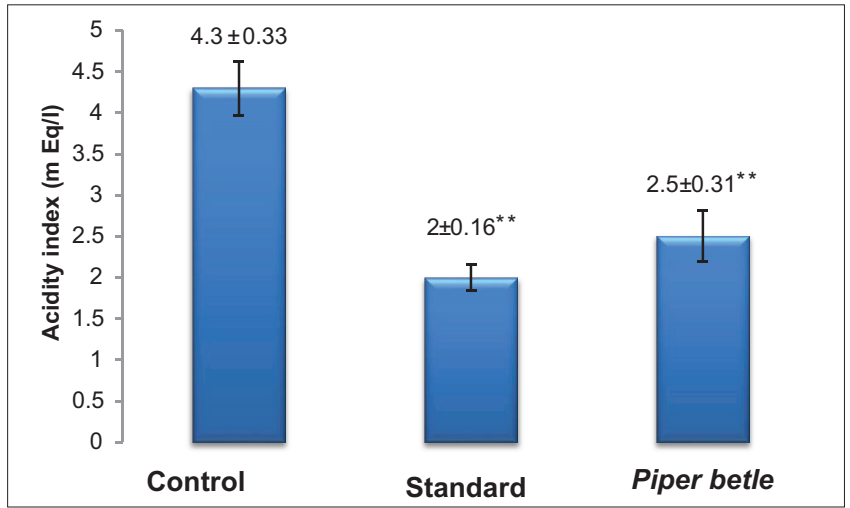

Fig. 1: Acidity index (mEq/l) in pyloric ligation model. All values are mean \pm SEM, $n=6,{ }^{*} \mathbf{p}<0.05,{ }^{* *} \mathbf{p}<0.01,{ }^{* * *} \mathbf{p}<0.001$, versus vehicle control 


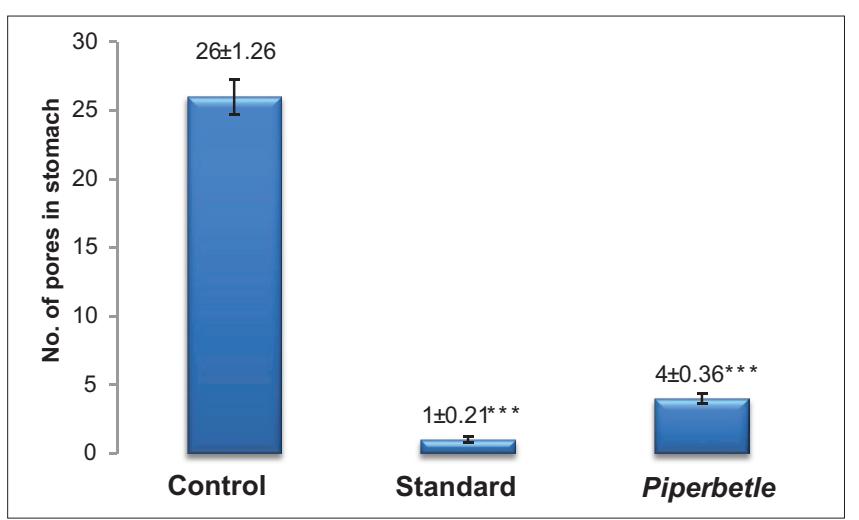

Fig. 2: Ulcer index (number of pores in the stomach) in water immersion model. All values are mean $\pm S E M, n=6$, ${ }^{*} \mathbf{p}<0.05,{ }^{* *} \mathbf{p}<0.01,{ }^{* * *} \mathbf{p}<0.001$, versus vehicle control

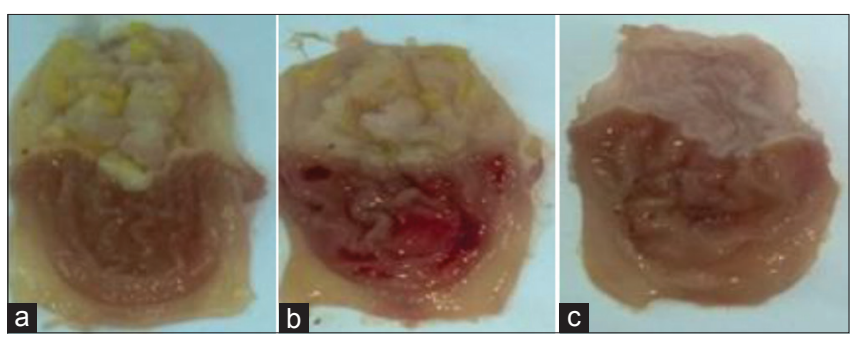

Fig. 3: Sample of dissected stomach and formation of an ulcer in the stress-induced antiulcer model. (a) Control, (b) standard (ranitidine), (c) Piper betle

A number of conditions such as ulcer, cancer, erosion, and aging are produced due to overloading of free radical, any compound, or drug which can scavenge these free radicals are called as an antioxidant and use to treat the number of ailments.

Any inflammatory condition uses to get worse in the presence of microbial load. H. pylori, Gram-negative bacteria came to the focus in 1982 and found responsible for worsening of the ulcerative condition.

Physiologically, histamine plays a major role in acid secretion in the parietal cell of the stomach. In any pathological condition, where histamine gets overactive, threats to create an ulcer.

The antioxidant, antimicrobial, and antihistaminic activities of $P$. betle are already scientifically established. The drug which shows antioxidant activity may also produce healing activity in the majority of the cases irrespective of open wound or ulcerative wound [24].

Antihistaminic is the type of drug that most responsible for ulcer protective action by inhibiting the histamine secretion from the parietal cell of the stomach. Antimicrobials are a very good choice of coprescription in the treatment of ulcers, which acts by its cidal or static action on microbes. Hence, a drug that already has the above said three major activities obvious to show its antiulcer or gastroprotective activity.

\section{CONCLUSION}

$P$. betle leaves were collected and extracted with $70 \%$ hydroalcoholic mixture and subjected for antiulcer activity using two experimental models, namely pyloric ligation model and stress-induced antiulcer model. The extract of $P$. betle has shown significant antiulcer activity in both the models. Its protective mechanism of the antiulcer effect probably due to numerous phytochemicals presents in the extract. This leaf can be encouraged for further evaluation which may expect a new promising herbal drug in the treatment of ulcer and related disorders.

\section{ACKNOWLEDGMENT}

The dissertation entitled "ANTI-ULCER ACTIVITY OF HYDROALCOHOLIC EXTRACT OF $P$. betle LEAF ON EXPERIMENTAL ANIMALS" is by far the most significant scientific accomplishment in our life and it would be impossible without the help of those people who supported us and believed in us. Then, we would like to express our most sincere appreciation to Professor Dr. Arnab Samanta, Principal, Netaji Subhas Chandra Bose Institute of Pharmacy. We owe our deepest gratitude to all of our Respected Teachers, non-teaching staff and management members of Netaji Subhas Chandra Bose Institute of Pharmacy for their continuous support, affection, and sincere advice to complete our investigation.

\section{AUTHORS' CONTRIBUTIONS}

All authors are equally contributed.

\section{CONFLICTS OF INTEREST}

There are no conflicts of interest.

\section{REFERENCES}

1. Chauhan I, Sharma A, Gangwar M, Gautam MK, Singh A, Goel RK. Gastric antiulcer and ulcer healing effects of Punica granatum L. Peel extract in rats: Role of offensive and defensive mucosal factors and oxidative stress. Int J Pharm Pharm Sci 2017;9:6-11.

2. Venkateswarlu K, Vijayabhaskar K, Krishna OS, Devanna N, Sekhar KC. Evaluation of anti-ulcer activity of hydro alcoholic extracts of Abutilon indicum, Helianthus annuus and combination of both against ethanol and pyloric ligation induced gastric ulcer in albino Wistar rats. Br J Pharm Res 2015;5:42.

3. Lanas A, Chan FK. Peptic ulcer disease. Lancet 2017;390:613-24.

4. Martin DF, Montgomery E, Dobek AS, Patrissi GA, Peura DA. Campylobacter pylori, NSAIDS, and smoking: Risk factors for peptic ulcer disease. Am J Gastroenterol 1989;84:1268-72.

5. Weil J, Colin-Jones D, Langman M, Lawson D, Logan R, Murphy M, et al. Prophylactic aspirin and risk of peptic ulcer bleeding. BMJ 1995;310:827-30.

6. Wakefield AJ, Sawyerr AM, Dhillon AP, Pittilo RM, Rowles PM, Lewis AA, et al. Pathogenesis of crohn's disease: Multifocal gastrointestinal infarction. Lancet 1989;2:1057-62.

7. Sharifi-Rad M, Fokou PVT, Sharopov F, Martorell M, Ademiluyi AO, Rajkovic J, et al. Antiulcer agents: From plant extracts to phytochemicals in healing promotion. Molecules 2018;23:E1751.

8. Tripathi KD. Essentials of Medical Pharmacology. $8^{\text {th }}$ ed. London: Jaypee Brothers Medical Publishers; 2019.

9. Usser M. Causes of peptic ulcer. A selective epidemiologic review. J Chronic Dis 1967;20:435-56.

10. Harini SS, Sougandhi PR, Tenkayala DS, Gopinath KR. Antioxidant activity (phenol and flavonoid content) of three different cultivars of Piper betle leaf. (Piperaceae). J Drug Deliv Ther 2018;8 Suppl 5:143-8.

11. Rekha VP, Kollipara M, Gupta BR, Bharath Y, Pulicherla KK. A review on Piper betle L.: Nature's promising medicinal reservoir. A J Ethol 2014;1:276-89.

12. Hajare R, Darvhekar VM, Shewale A, Patil V. Evaluation of antihistaminic activity of Piper betle leaf in guinea pig. Afr J Pharm Pharmacol 2011;5:113-7

13. Datta A, Ghoshdastidar S, Singh M. Antimicrobial property of Piper betle leaf against clinical isolates of bacteria. Int J Pharm Sci Res 2011;2:104-9.

14. Hung CR, Wang PS. Gastric oxidative stress and hemorrhagic ulcer in Salmonella typhimurium infected rats. Eur J Pharmacol 2004;491:61-8.

15. Walum E. Acute oral toxicity. Environ Health Perspect 1998;106 Suppl 2:497-503.

16. Kokate CK, Purohit AP, Gokhale SB. Pharmacognosy. $30^{\text {th }}$ ed. Pune, India: Nirali Prakashan; 2005.

17. Kulkarni SK. Hand Book of Experimental Pharmacology. $4^{\text {th }}$ ed. New Delhi: Vallabh Prakashan; 2012.

18. Jadhav SA, Prasanna SM. Evaluation of antiulcer activity of Ziziphus oenoplia (L) Mill. Root in rats. Asian J Pharm Clin Res 2011;1:92-5.

19. Deshpande SS, Shah GB, Parmar NS. Antiulcer activity of 
Tephrosia purpurea in rats. Indian J Pharmacol 2003;35:168-72.

20. Sayed DA, Fahmy SR, Soliman AM, Hussein NS. Antiulcerogenic efficacy of ethanolic extract of Vitis vinifera leaves in rats. Int J Pharm Pharm Sci 2016;8:163-72.

21. Kitagawa H, Fujiwara M, Osumi Y. Effects of water-immersion stress on gastric secretion and mucosal blood flow in rats. Gastroenterology 1979;77:298-302.

22. Malairajan P, Gopalakrishnan G, Narasimhan S, Veni KJ. Evalution of anti-ulcer activity of Polyalthia longifolia (Sonn.) thwaites in experimental animals. Indian J Pharmacol 2008;40:126-8.

23. Gill NS, Garg M, Bansal R, Sood S, Muthuraman A, Bali M, et al. Evaluation of antioxidant and antiulcer potential of Cucumis sativum L. seed extract in rats. Asian J Clin Nutr 2009;1:131-8.

24. Majumdar M, Samanta A, Roy A. Study of wound healing activity of different formulations of Nigella sativa seed extract. Res J Pharm Technol 2016;9:2097-105. 